\title{
The earliest fossil flower bugs (Heteroptera: Cimicomorpha: Cimicoidea: Vetanthocoridae) from the Middle Jurassic of Inner Mongolia, China
}

\author{
WeNIING HOU ${ }^{1}$, YunZHI YAO $^{1,2 *}$, WeItING ZHANG ${ }^{1}$ and Dong REN ${ }^{1}$ \\ ${ }^{1}$ Key Lab of Insect Evolution and Environmental Changes, Capital Normal University, Beijing 100048, China; \\ e-mails: houwenjing7555@163.com; yaoyz100@gmail.com; zhangweitinghao@163.com; rendong@mail.cnu.edu.cn \\ ${ }^{2}$ State Key Laboratory of Palaeobiology and Stratigraphy, Nanjing Institute of Geology and Palaeontology, CAS, Nanjing 210008, \\ China
}

Key words. Heteroptera, Vetanthocoridae, fossil, Middle Jurassic, Inner Mongolia

\begin{abstract}
One new genus with two new fossil species, Pumilanthocoris gracilis gen. n. sp. n. and P. obesus gen. n. sp. n., which were found in the Middle Jurassic Jiulongshan Formation of Inner Mongolia, China, are described and illustrated. These are the earliest fossil records of Vetanthocoridae.
\end{abstract}

\section{INTRODUCTION}

The Anthocoridae (sensu lato) are sometime referred to as flower bugs or minute pirate bugs and are widespread in all zoogeographical regions (Zheng, 1999). Most members of this family are predators of other insects (e.g. aphids and thrips) and mites in decaying vegetable matter or sometimes under bark. They also feed on vegetable matter, especially pollen (Popov \& Herczek, 2001).

Flower bugs comprise three modern families: Anthocoridae (sensu stricto), Lyctocoridae and Lasiochilidae (Schuh \& Štys, 1991), and one fossil family: Vetanthocoridae (Yao et al., 2006a). The extant group includes about 80 genera and 500 species (Bu \& Zheng, 2001); their body lengths range from about 1.4 to $4.5 \mathrm{~mm}$. The fossil flower bugs consist of 13 genera and 15 species. Five representatives of Anthocoridae are described: Temnostethus blandus Statz \& Wagner, 1950 from the Oligocene of Germany; Mesanthocoris brunneus Hong \& Wang, 1990 from the Lower Cretaceous of Shandong Province, China; Eoanthocoris cretaceus and E. ghidarinus Popov, 1990 from the Lower Oligocene of Germany; Persephonocoris kulickae Popov \& Herczek, 2001 from Eocene Baltic amber. Ten representatives of Vetanthocoridae are described: Liaoxia longa Hong, 1987, Vetanthocoris decorus, V. longispicus, Collivetanthocoris rapax, Byssoidecerus levigata, Mecopodus xanthos, Curvicaudus ciliatus, Crassicerus furtivus, Curticerus venustus and Pustulithoracalis gloriosus Yao, Cai \& Ren, 2006a, all from the Yixian Formation, Lower Cretaceous, Chaomidian Village, Beipiao City, Liaoning Province, China. In addition, two undescribed specimens of fossil flower bugs are reported from the Lower Cretaceous of Australia (Jell \& Duncan, 1986) and the Lower Cretaceous amber of Canada (McAlpine \& Martin, 1969).

Our fossil specimens were collected from Daohugou Village, Ningcheng Country, Inner Mongolia, China. The section at Daohugou Village is composed of grey tuffaceous sandstone and sandy mudstone (Ren et al., 2002). The climate at the time of its deposition was humid and warm-temperate (Tan \& Ren, 2002). Well-preserved fossil insects (Yao, 2006b; Liu et al., 2007, 2008; Ren et al., 2010), conchostracans (Zhang \& Shen, 1987) and some dinosaurs (Ji \& Yuan, 2002) are described from the Daohugou bed. The geological age of this deposit is considered to be the Jiulongshan Formation, Middle Jurassic (Ren et al., 2002; Shen et al., 2003; Chen et al., 2004; Liu et al., 2004; Zhou et al., 2007).

Fossil insects of Middle Jurassic from northern China are mainly distributed north of the Yellow River, from east of Liaodong to west of Xinjiang. There is an abundance of fossil insects in this region. The insects of the region were named Yanliao Entomofaunae by Hong (1983). The Jiulongshan Formation of the Middle Jurassic in Daohugou Village, Ningcheng County, Inner Mongolia, Jiulongshan Formation of the Middle Jurassic in Jibei and Haifanggou Formation of the Middle Jurassic in Liaoxi are different names for the same strata in China. Up to now, 18 orders and nearly 300 species of fossil insects are reported from these three localities (Liu et al., 2010).

\section{MATERIAL AND METHODS}

All specimens are deposited at the Key Laboratory of Insect Evolution and Environmental Change, Capital Normal University, Beijing, China. The specimens were examined under a Leica MZ12.5 dissecting microscope and illustrated with the aid of a drawing tube attached to the microscope. Drawings were scanned into computer using an EPSON5100 and revised with Adobe Photoshop CS3. Taxonomy and morphological terminology mainly follow Schuh \& Slater (1995). Wing veination terminology follows Zheng (1999).

Body length was measured along the midline from the anterior margin of the head to the apex of abdomen. Body width was

\footnotetext{
* Corresponding author.
} 

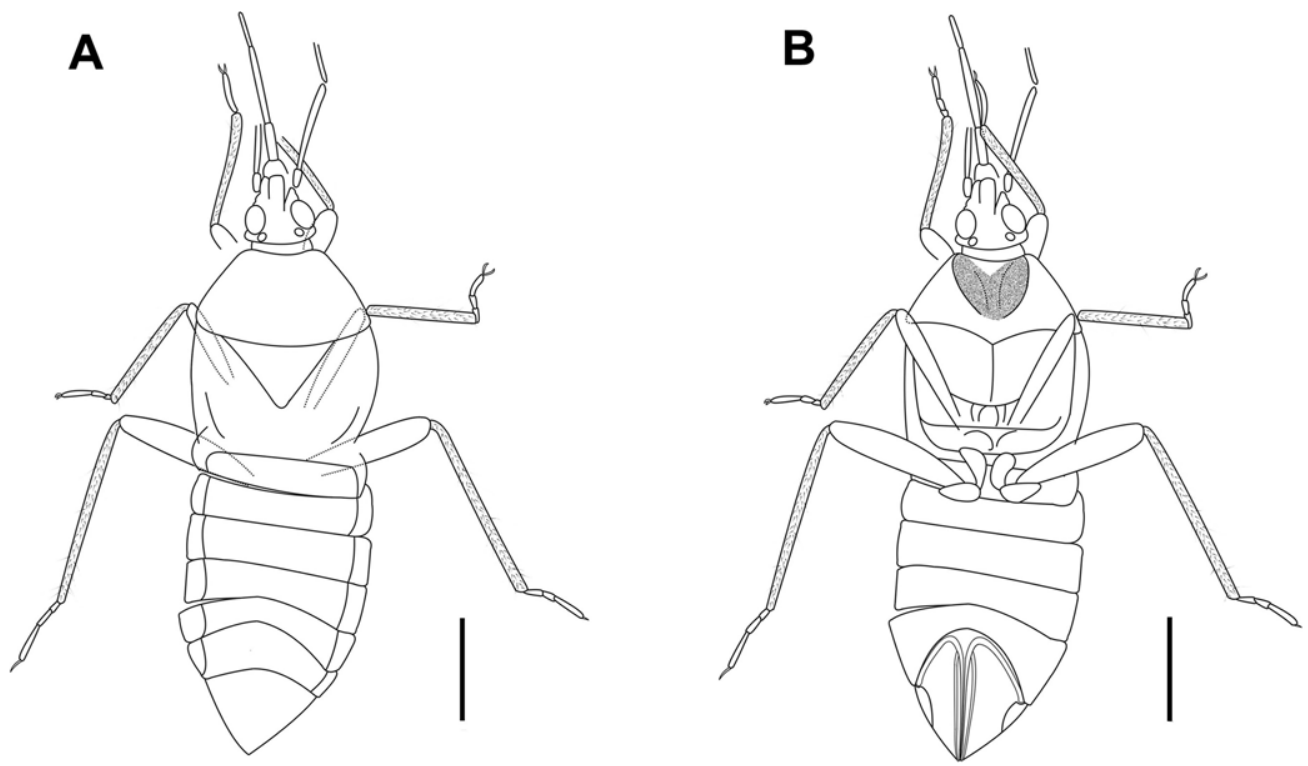

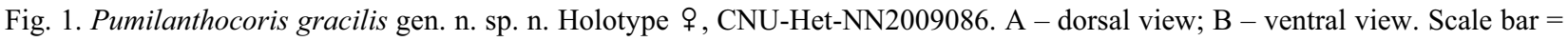
$1 \mathrm{~mm}$.

measured at the maximal width of the body. The lengths of the pronotum and scutellum were measured along the midline. The length of the hemelytron was measured from the base to its apex. The length of the corium was measured from the base of the hemelytron to the apex of the corium. All measurements are given in millimeters $(\mathrm{mm})$.

\section{SYSTEMATIC PALEONTOLOGY}

\section{Suborder: Heteroptera Latreille, 1810}

Infraorder: Cimicomorpha Leston, Pendergrast \& Southwood, 1954

Superfamily: Cimicoidea Stephen, 1829

Family: Vetanthocoridae Yao, Cai \& Ren, 2006a

Tribe: Vetanthocorini Yao, Cai \& Ren, 2006a

\section{Genus: Pumilanthocoris gen. $n$.}

Type species. Pumilanthocoris gracilis sp. n. (Figs 1-3)

Diagnosis. Body relatively small, sides sub-parallel, dorsal surface smooth, without punctation and setae. Head porrect, width slightly shorter than or sub-equal to length; clypeus prominent, slightly longer than mandibular plate; rostrum tapering, length sub-equal to head and pronotum combined, 4-segmented, extending to mid coxae, first segment shortest, third segment much longer than first, second and fourth segments combined; antennae 4-segmented, third and fourth antennal segments thinner than second segment, first segment shortest and thickest, second longest, shorter than third and fourth segments combined; eyes oval, diameter in dorsal view subequal to interocular space; ocelli situated behind level of posterior margins of eyes, interocular space wider than interocellar space. Pronotum trapezoidal, with collar; scutellum triangular, shorter than pronotum along midline, wider than long. Hind leg longer than mid leg, fore and hind coxae narrowly separated, mid coxae widely separated, fore and mid femora sub-equal in length to corresponding tibiae, tibiae with dense setae, tarsus 3-segmented, sub-equal in thickness, third the longest and with symmetrical claws. Hemelytra macropterous, extending beyond or reaching tip of abdomen, corium with distinct median fracture, costal fracture $(=$ embolar fracture) at middle of anterior margin of forewing, clavus large, claval commissure longer than scutellum, Pcu and A (1A) just visible on clavus, membrane with several indistinct longitudinal veins. Abdominal terga II-VII with dorsal laterotergites, distinctly longer than wide, eighth abdominal sternum distinctly narrowed; ovipositor long, occupying last two abdominal segments.

Distribution. China.

Etymology. Generic name is a combination of the Latin words pumilus (dwarf) and Anthocoris (an extant genus).

Remark. Based on the following characters Pumilanthocoris can be placed within the Anthocoridae s. 1. (after Schuh \& Štys, 1991; Schuh \& Slater, 1995; Schuh et al., 2009): head porrect; eyes large, ocelli present; rostrum 4-segmented, first segment very short, third segment longest; antennae 4-segmented third and fourth segments thinner than second; hemelytra macropterous, corium with deep costal fracture and median fracture, cuneus present; membrane with more than 10 free longitudinal veins, without cross veins or living cell; apophysis absent internally on abdominal sternum 7 in female; male abdominal segment 8 normally developed and exposed.

In addition, based on the following characters Pumilanthocoris can be placed within Vetanthocoridae (after Yao et al., 2006a): third and fourth antennal segments without setae; costal fracture ending at middle of anterior margin of corium, membrane with over 10 longitudinal veins; abdominal terga II-VII with dorsal laterotergites. The new genus can be assigned to the tribe Vetanthocorini because of the following combination of features: third and fourth antennal segments thinner than second segment, dorsal laterotergites present, ventral laterotergites fused with sternum. 
Within the tribe Vetanthocorini, the new genus is closely related to Mecopodus Yao, Cai \& Ren, 2006a, but differs from the latter as the third segment of the rostrum is slightly longer than first, second and fourth segments combined (vs. third distinctly longer than first, second and fourth segments combined); fourth segment of rostrum is longer than the second (vs. fourth segment slightly shorter than second); pronotum has a collar (vs. pronotum without collar).

\section{Pumilanthocoris gracilis sp. n. (Figs 1-3)}

Description. Body narrow and elongated, about 3.1 times as long as wide. Head observably shorter than pronotum, length slightly longer than width; antennae long, second segment with delicate setae, apical 1/5 black, about 1.5 times as long as third, fourth segment shorter than third. Pronotum about 1.9 times as wide as long, length of posterior margin about twice that of anterior margin, sides straight and convex, anterior and posterior margins weakly concave, anterior and posterior angles rounded; scutellum shorter than pronotum along midline, 1.8 times as wide as long. Hind legs distinctly longer than fore and mid legs, femora stout, thicker than corresponding tibiae, fore femora 2.4 times as thick as tibiae, mid femora 1.6 times as thick as tibiae, hind femora 2.7 times as thick as tibiae, fore and mid tarsi almost 0.25 times as long as corresponding tibiae; third tarsus longer than first and second tarsi combined, hind tarsi longer than fore and mid tarsi, almost 0.5 times as long as hind tibiae. Hemelytra reaching tip of abdomen, clavus wide, large, nearly 4.8 times as long as wide, almost 0.6 times length of hemelytron; abdomen as wide as pronotum, connexivum relatively narrow, almost 0.08 times width of abdomen.

Dimensions (in mm). Body length 5.60-5.75 (\$), 6.07 ( $₫$ ); maximum width of body $1.60-1.80$; head length 0.70 , width 0.40 ; length rostral segments I-IV: $0.17,0.22,0.78,0.32$; length antennal segments I-IV: $0.22,0.79,0.53,0.45$; diameter of eyes 0.28 , interocular space 0.28 , interocellar space 0.26 ; width of collar 0.6 ; pronotum length 1.70 , width 0.90 ; scutellum length 0.60 , width 1.1 ; hemelytron length 4.10 , width 1.20 ; clavus length 2.29 , width 0.48 ; length fore leg: tibia 1.1 , tarsomeres I-III: $0.08,0.11,0.21$, total length 0.4 ; length middle leg: femur 1.12 , tibia 1.11 , tarsomeres I-III: $0.07,0.11,0.24$, total length 0.42 ; length hind leg: femur 1.40 , tibia 1.46 , tarsomeres I-III: $0.10,0.19,0.41$, total length 0.70 ; length ovipositor 1.05 .

Type material. Holotype, + , CNU-HET-NN2009086 (dorsoventrally compressed); paratypes, 7 9 , CNU-HETNN2010175 (dorsoventrally compressed), CNU-HETNN2010221 (dorsoventrally compressed), CNU-HETNN2010298 (dorsoventrally compressed), CNU-HETNN2010303 (dorsoventrally compressed), CNU-HETNN2010304PC (dorsoventrally compressed, part and counterpart), CNU-HET-NN2010305 (dorsoventrally compressed), CNU-HET-NN2010308PC (dorsoventrally compressed, part and counterpart); $1 \delta^{\star}$, CNU-HET-NN2010307 (dorsoventrally compressed).

Locality and horizon. Daohugou Village, Shantou Township, Ningcheng County, Inner Mongolia, China. Jiulongshan Formation, Middle Jurassic.

Etymology. The specific name is derived from the Latin word gracilis (slender).

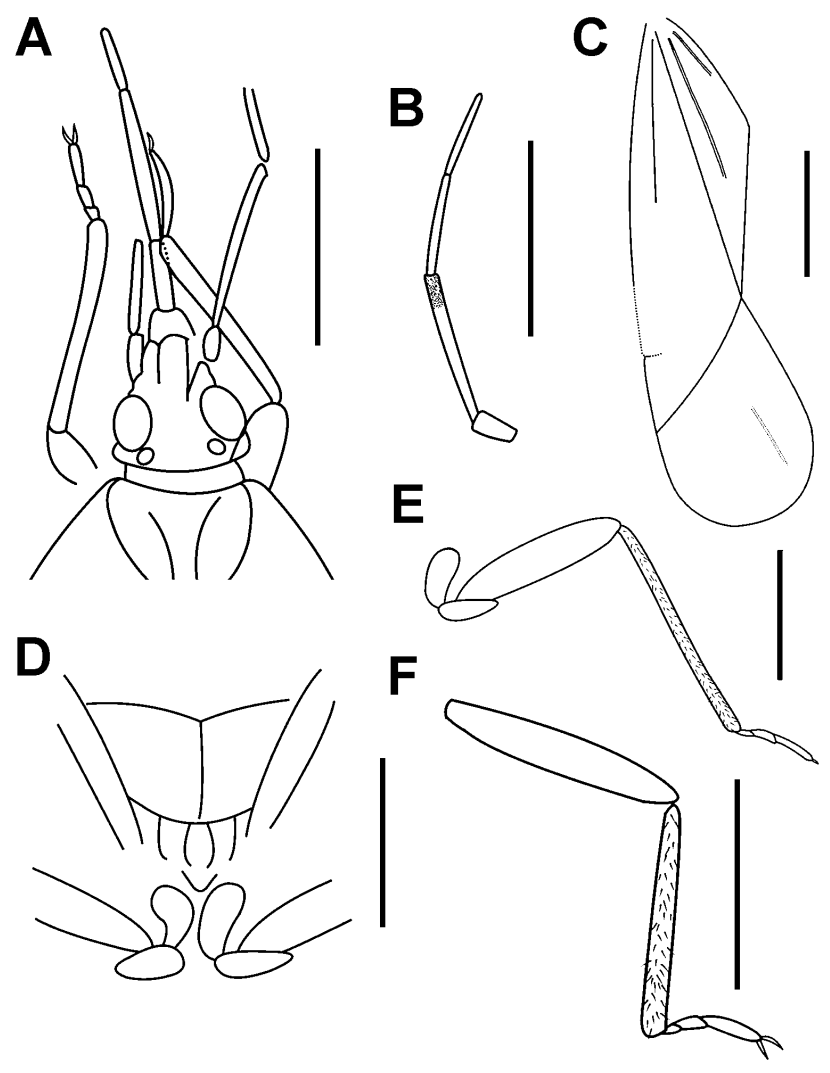

Fig. 2. Pumilanthocoris gracilis gen. n. sp. n. A - holotype $\%$ head, CNU-Het-NN2009086; B - paratype + , antenna, CNU-Het-NN2010175; C - paratype + , hemelytron, CNU-HetNN2010175; D - holotype $\$$, mid coxae, hind coxae and femora, CNU-Het-NN2009086; E - holotype + , mid leg, CNUHet-NN2009086; F - holotype $\subsetneq$, hind leg, CNU-HetNN2009086. Scale bar $=1 \mathrm{~mm}$.

\section{Pumilanthocoris obesus sp. n. (Figs 4, 5)}

Description. Body relatively small, oval, about 2.4 times as long as wide. Head width sub-equal to length, slightly longer than pronotum; rostrum 4-segmented, first segment thick and short; second segment of antennae with delicate setae, apical 1/5 black, about 2.2 times as long as third, 2.7 times as long as fourth; eyes somewhat prominent. Pronotum 2.5 times as wide as long, anterior margin about 0.4 times as long as posterior margin, sides very convex, anterior and posterior margins weakly concave, anterior and posterior angles rounded; scutellum longer than pronotum along midline, 1.5 times as wide as long. Hind legs longer than fore and mid legs; fore and hind coxae narrowly separated, mid coxae widely separated; femora stout, over 2 times as thick as corresponding tibiae, fore and mid femora sub-equal to corresponding tibiae in length; tarsus 3-segmented, sub-equal in thickness, third longest, mid tarsi almost 0.2 times as long as mid tibiae. Hemelytra distinctly extending beyond abdominal tip, corium with deep median fracture, clavus relatively small, claval commissure shorter than scutellum. Abdomen oval, wider than pronotum, connexivum slightly wider, almost 0.11 times width of abdomen. 

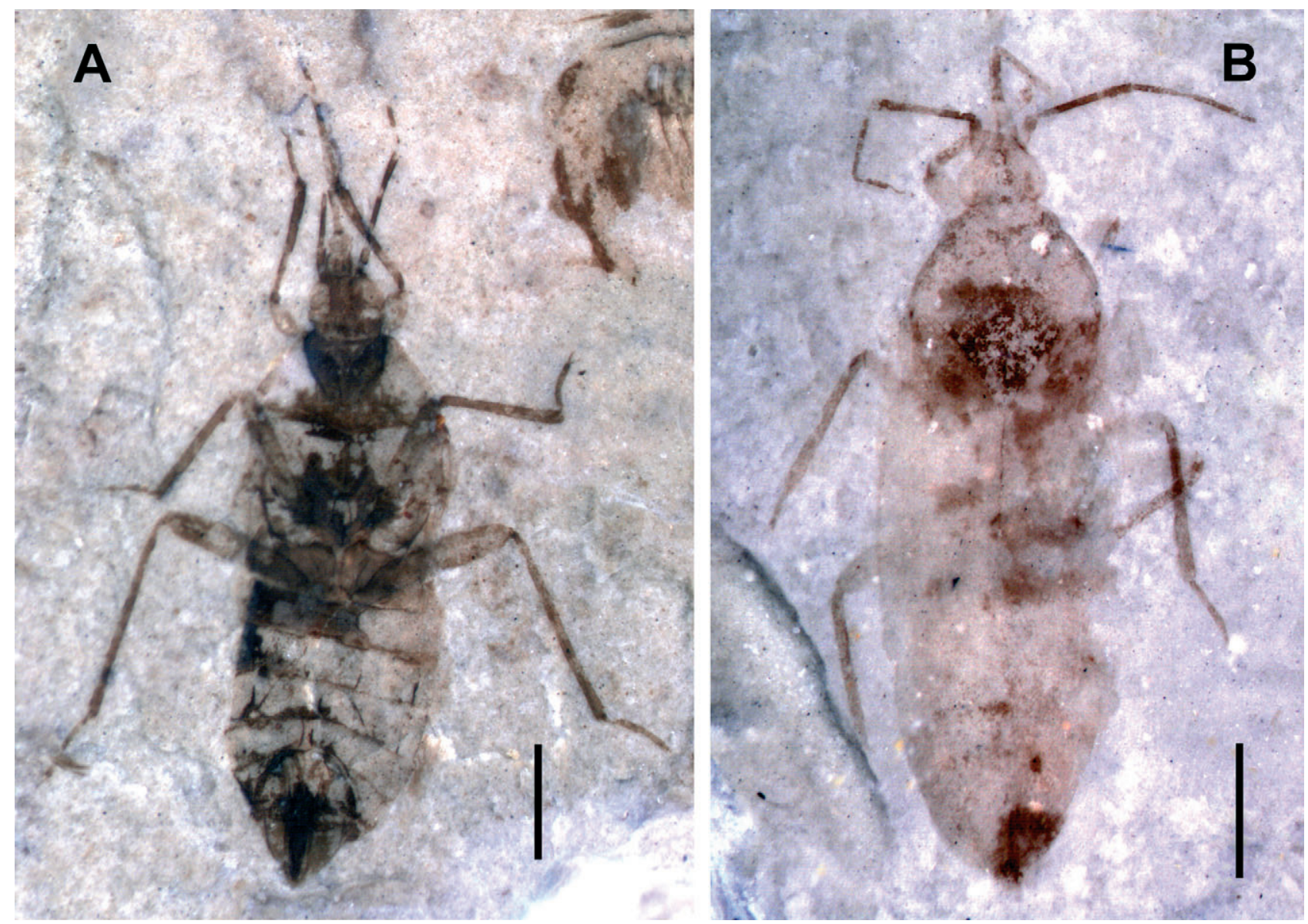

Fig. 3. Pumilanthocoris gracilis gen. n. sp. n. A - holotype $९$, CNU-Het-NN2009086; B - paratype $\subsetneq$, CNU-Het-NN2010175. Scale bar $=1 \mathrm{~mm}$.

Dimensions (in mm). Body length 5.04-5.69 (ㅇ) , 5.76 (む); maximum width of body 2.10 ; head length 0.74 , width 0.70 ; length rostral segments I-IV: $0.19,0.15$, ?, ?; length antennal segments I-IV: $0.28,1.15,0.52,0.43$; eyes diameter 0.28 , interocular space 0.43 ; width collar 0.60 ; length pronotum 0.67 , width anterior margin 0.63 , width posterior margin 1.64 ; scutellum length 0.88 , width 1.31 ; length fore leg: femur 1.15 , tibia 1.23; length middle leg: femur 1.3 , tibia 1.20 , tarsomeres I-III: $0.06,0.14,0.23$, total 0.43 ; length hind leg: tibia 1.90 , tarsomeres I-III: $0.10,0.17,0.29$, total 0.56 ; clavus length 0.40 , width 1.55 ; length ovipositor 1.24 .

Type material. Holotype, $q$, CNU-HET-NN2009087PC (dorsoventrally compressed, part and counterpart); paratypes, 11 , CNU-HET-NN2009088 (dorsoventrally compressed), CNUHET-NN2010181PC (dorsoventrally compressed, part and counterpart), CNU-HET-NN2010222PC (dorsoventrally compressed), CNU-HET-NN2010292 (dorsoventrally compressed), CNU-HET-NN2010294 (dorsoventrally compressed), CNUHET-NN2010295 (dorsoventrally compressed), CNU-HETNN2010296 (laterally compressed), CNU-HET-NN2010297 (laterally compressed), CNU-HET-NN2010300 (dorsoventrally compressed), CNU-HET-NN2010301 (dorsoventrally compressed), CNU-HET-NN2010302 (dorsoventrally compressed); 1 ${ }^{\star}$, CNU-HET-NN2010299 (dorsoventrally compressed); 2 gender unknown, CNU-HET-NN2010293 (dorsoventrally compressed), CNU-HET-NN2010306 (dorsoventrally compressed).

Locality and horizon. Daohugou Village, Shantou Township, Ningcheng County, Inner Mongolia, China. Jiulongshan Formation, Middle Jurassic.
Etymology. The name is derived from the Latin word obesus (corpulent).

Remark. There are big differences between $P$. gracilis sp. n. and $P$. obesus sp. n.: average body length of $P$. gracilis is longer than $P$. obesus. Body shape, $P$. gracilis tenuous, 3.1 times as long as wide, and P. obesus elliptical about 2.4 times as long as wide; $P$. gracilis head shorter than pronotum, but $P$. obesus head slightly longer than pronotum; $P$. gracilis scutellum shorter than pronotum along midline, but $P$. obesus scutellum longer than pronotum along midline; $P$. gracilis fore femora 2.4 times as thick as tibiae, mid femora 1.6 times as thick as tibiae, hind femora 2.7 times as thick as tibiae, tarsi almost 0.25 times as long as corresponding tibiae, but $P$. obesus femora stout, over 2 times as thick as corresponding tibiae, tarsi almost 0.36 times as long as corresponding tibiae; finally, $P$. gracilis hemelytra reach tip of abdomen, clavus large, commissure longer than scutellum, but $P$. obesus hemelytra extend beyond abdominal tip, clavus relatively small, claval commissure shorter than scutellum.

\section{DISCUSSION}

Shcherbakov (2007) described several fossil heteropterans based on a few poorly preserved specimens, most of them with only part of a forewing. In his paper, he rec- 


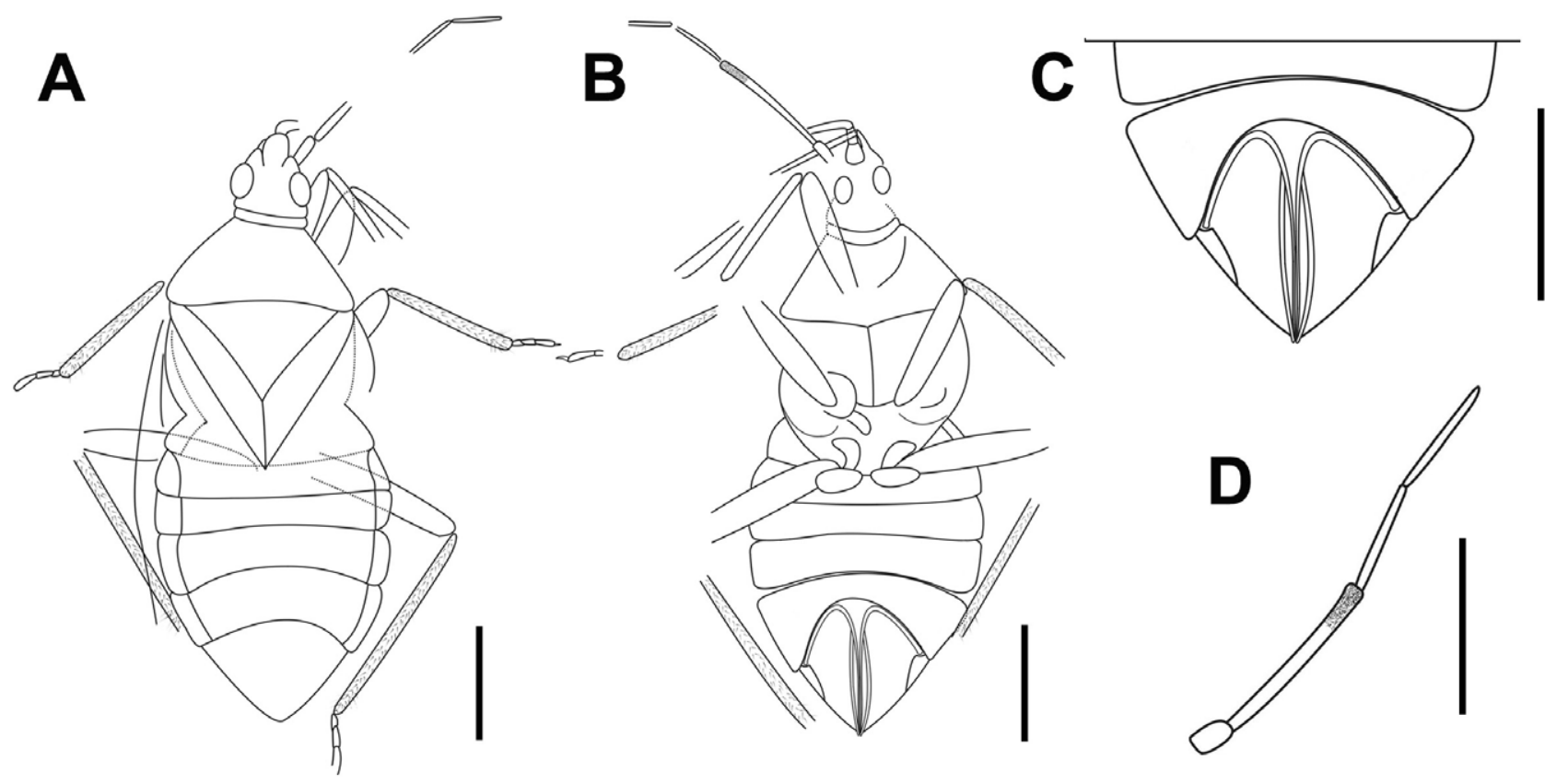

Fig. 4. Pumilanthocoris obesus gen. n. sp. n. A - holotype + , dorsal view, CNU-Het-NN2009087PC; B - holotype $q$, ventral view, CNU-Het-NN2009087PC; C - holotype + , ovipositor, CNU-Het-NN2009087PC; D - paratype + , antenna, CNU-HetNN2010181PC. Scale bar $=1 \mathrm{~mm}$.

ognized that Velocipedidae is a subfamily (Velocipedinae) of Nabidae, and the subfamily Velocipedinae includes three tribes Vetanthocorini, Darniopseini and Velocipedini. He describes three genera and species ( Saldonabis proteus, Juracipeda popovi and Izinabis kerzhneri), which he assigned to the subfamily Velocipedinae. He also transferred Darniopsis tragopea BeckerMigdisova 1958 to the Velocipedinae. All of the above conclusions are mainly based on some characters of the membrane of the forewing, such as shape, size and basic number of cells and veins etc. Shcherbakov identified many characters but also ignored some important characters such as the costal fracture, costal area and the veins on the corium. According to the description, illustrations and photographs in the original paper, all the abovementioned species have the following characters: hemelytron divided into a distinct corium and membrane, corium with deep costal fracture, with corium-membrane boundary sub-parallel, cuneus absent, Sc, $\mathrm{R}$ and $\mathrm{M}$ diverging from a single point. These characters are the main diagnostic features of the Pachymeridiidae, an extinct true bug family that is considered to be ancestral to the Coreoidea (sensu lato, including Coreoidea, Pyrrhocoroidea and Lygaeoidea) and lived during the Mesozoic (Handlirsch, 1906; Popov \& Wootton, 1977; Shcherbakov \& Popov, 2002; Yao et al., 2008). Although we did not examine these fossil specimens, based on the available evidence we prefer to treat them as representatives of the Pachymeridiidae. Furthermore, during the Mesozoic, veins on the membrane of Pachymeridiidae diversified (Popov \& Wootton, 1977; Yao et al., 2008). So we can't classify the Pachymeridiidae based on some features of the forewing membrane or only one poorly preserved specimen.
Shcherbakov (2007) prefers to use Kerzhner's classification system (Kerzhner, 1981) in which the Pachynomidae are not included but the Medocostidae and Velocipedidae are included in the Nabidae. Schuh \& Stys (1991) have defined the Nabidae as including only the subfamilies Nabinae and Prostemmatinae, and Naboidea as including two families the Nabidae and Medocostidae, based on a cladistic analysis, which was subsequently adopted (e.g. Schuh \& Slater, 1995; Zheng, 1999; Ke, 2006; Schuh et al., 2009). According to the Schuh \& Stys's (1991) and Schuh's et al. (2009) studies, the Naboidea is the sister group of Cimicoidea and the monophyly of the Naboidea is well supported by a series of synapomophic characters: the presence of one to three cells on the membrane, distal sector of $R+M$ in hindwing branching, apophysis present internally in abdominal sternum 7 in female, male abdominal segment 8 reduced and for the most part telescoped within segment 7, and the establishment of the Cimicoidea is supported by a series of characters, e.g. membrane with some free veins, rarely with 1 long closed cell with no emanating veins, and microscopic features such as paramere, aedeagus and micropyle.

We checked all the holotypes of the Vetanthocoridae and did not find cells on the membrane, but there were more than 10 free veins on the membrane, a deep costal fracture and median fracture on the corium, cuneus present, internal apophysis absent in abdominal sternum 7 of female and abdominal segment 8 of male normally developed and exposed. Therefore, we consider that the six genera and seven species of Vetanthocorini belong to the Vetanthocoridae and should not be transferred to the Nabidae; the Vetanthocoridae are representatives of the Cimicoidea. 

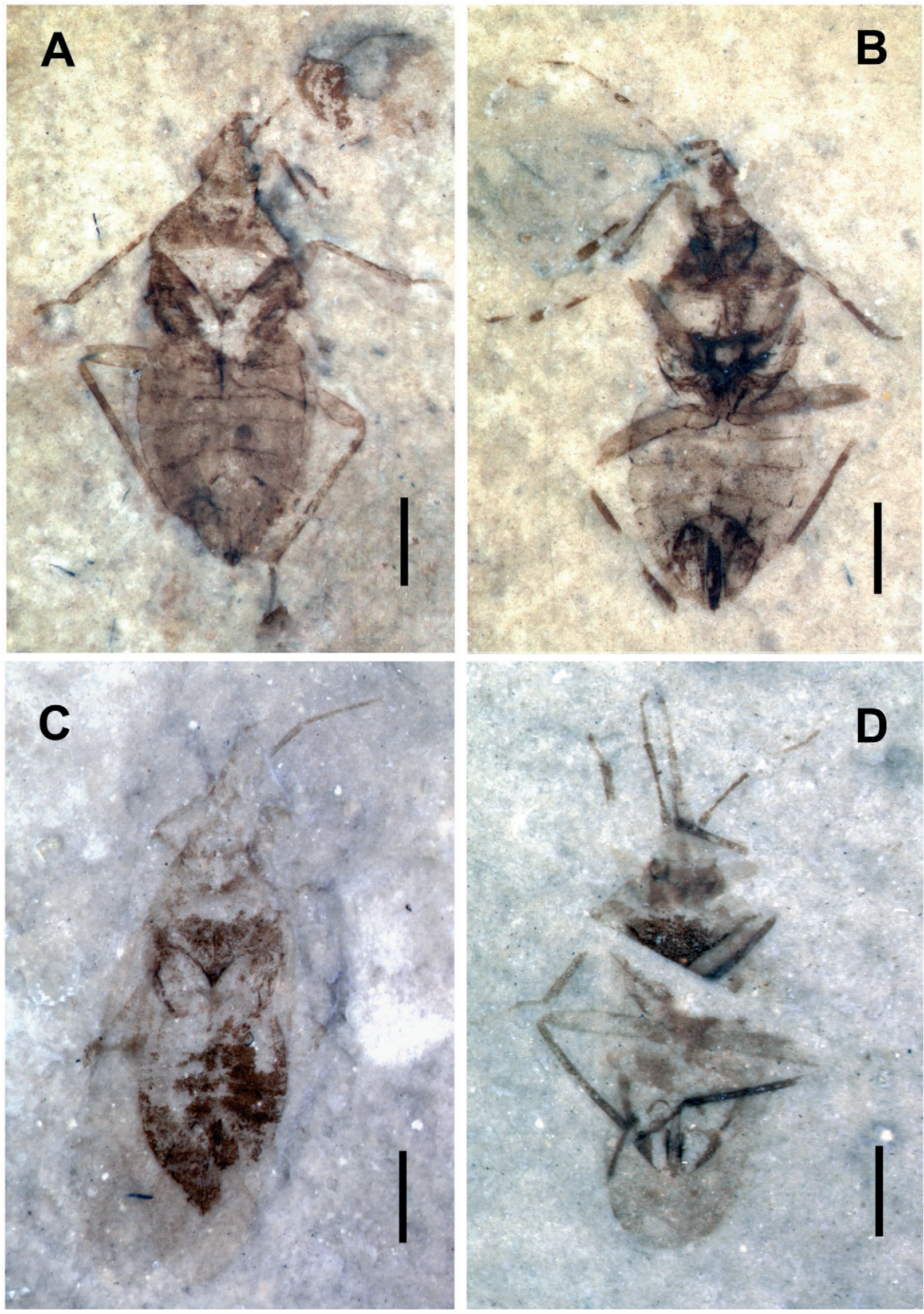

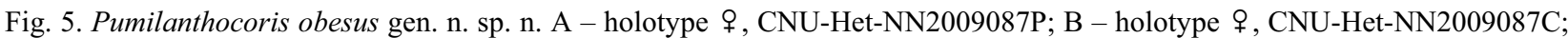

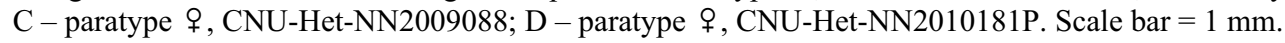


It is considered that flower bugs have existed since the Late Jurassic (Shcherbakov \& Popov, 2002). However, recently, 24 new fossils, including one new genus and two new species were discovered in the Jiulongshan Formation, Middle Jurassic, Daohugou Village, Shantou Township, Ningcheng County, Inner Mongolia, China. These fossil flower bugs are considered to the earliest flower bugs recorded in the world so far. From the Middle Jurassic to Lower Cretaceous, a lot of species of fossil insects occur along with the fossil flower bugs, such as larvae of Hemiptera and adults or larvae of Diptera, Catiniidae, aphids etc. (Hong, 1998, 1999; Liu et al., 2010). In addition, ferns, conifers, cycads and gingko were the main soecies of plants in this period (Sun et al., 2001; Deng \& Chen, 2001). So we conjecture that the flower bugs extant in the Middle Jurassic were predatory on small arthropods and lived on gymnosperms.

Connexivums or dorsal laterotergites were present on all the abdominal segments of fossil flower bugs in the Middle Jurassic and Lower Cretaceous (Yao et al., 2006a). All the fossil flower bugs from Lower Cretaceous to Oligocene (Statz \& Wagner, 1950; Popov \& Herczek, 2001) and modern Anthocoridae s.lat., however lack connexivums and have reduced dorsal laterotergites on their abdomens, with in most species only abdominal segments I-III with dorsal laterotergites (Carayon, 1972; Bu \& Zheng, 2001; Ke, 2006). Ke (2006) considers that the general evolutionary tendency of abdominal terga in the Cimicoidea is from undifferentiated mediotergites and dorsal laterotergites to divided mediotergites and dorsal laterotergites. In the Anthocoridae s.lat., she also considers that abdominal segments I-III with dorsal laterotergites is apomorphic and only the first segment of abdomen with dorsal laterotergites is plesiomorphic. But based on fossil records and our fossil specimens, laterotergites present along the abdominal margin is a plesiomorphic character in the Anthocoridae s.lat..

ACKNOWLEDGEMENTS. We appreciate Yu.A. Popov, Paleontological Institute, Russian Academy of Sciences, supplying us with important references. This research was funded by grants from the National Natural Science Foundation of China (No. 30800095, 31071964, 40872022); National Basic Research Program of China (973 Program) (No. 2012CB821906); Nature Science Foundation of Beijing (No. 5082002); the PHR Project of Beijing Municipal Commission of Education (No. 20090509, 201107120) and the State Key Laboratory of Palaeobiology and Stratigraphy (Nanjing Institute of Geology and Palaeontology, CAS) (No. 123114).

\section{REFERENCES}

Becker-Migdisova E.E. 1958: New fossil Homoptera. Part 1. Mater. Osnov. Paleont. 2: 57-67 [in Russian].

Bu W.J. \& Zheng L.Y. 2001: Fauna Sinica, Insecta, Vol. 24, Hemiptera: Lasiochilidae, Lyctocoridae and Anthocoridae. Science Press, Beijing, 267 pp. [in Chinese, English abstr.].

CARAYON J. 1972: Caractères systématiques et classification des Anthocoridae (Hemiptera). Ann. Soc. Entomol. Fr. 8: 309-349.

Chen W., Ji Q., Liu D.Y., Zhang Y., Song B. \& Liu X.Y. 2004: Isotope geochronology of the fossil-bearing beds in the
Daohugou area, Ningcheng, Inner Mongolia. Geol. Bull. China 23: 1165-1169.

Deng S.H \& Chen F. 2001: The Early Cretaceous Filicopsida from Northeast China. Geological Publishing House, Beijing, 249 pp. [in Chinese, English abstr.].

HandliRsch A. 1906-1908: Die fossilen Insekten und die Phylogenie der rezenten Formen. Engelmann, Leipzig, 1430 pp.

Hong Y.C. 1983: Middle Jurassic Fossil Insects in North China. Geological Publishing House, Beijing, 223 pp. [in Chinese].

Hong Y.C. 1998: Present study condition of Chinese aphids (Insecta: Homoptera) and its problems. (I) Summation of Chinese fossil aphids, emendation of aphid taxon and making of a new Chinese fossil aphid list. Beijing Geol. 10: 9-18 [in Chinese, English abstr.].

Hong Y.C. 1999: Present study condition of Chinese Aphids (Insecta: Homoptera) and its problems. (II) The problems of theoretical basic knowledge on the aphidobiology and developing order of aphid venation. Beijing Geol. 11: 1-10 [in Chinese, English abstr.].

Hong Y.C. \& WANG W.L. 1987: Miocene Heteroptera and Coleoptera (Insecta) from Shanwang of Shandong Province, China. J. Lanzhou Univ (Nat. Sci.) 23: 116-124 [in Chinese, English abstr.].

Hong Y.C. \& WANG W.L. 1990: Fossil insects from the Laiyang Formation. In: The Stratigraphy and Palaeontology of Layang Basin Shandong Province. Geological Publishing House, Beijing, pp. 89-105 [in Chinese].

JeLl P.A. \& Duncan P.M. 1986: Invertebrates, mainly insects, from the freshwater, Lower Cretaceous, Koonwarra Fossil Bed (Korumburra Group), South Gippsland,Victoria. In Jell P.A. \& Roberts J. (eds): Plants and Invertebrates from the Lower Cretaceous Koonwarra Fossil Bed. South Gippsland, Victoria, pp. 111-127.

JI Q. \& YUAN C.X. 2002: Discovery of two kinds of protofeathered pterosaurs in the Mesozoic Daohugou Biota in the Ningcheng region and its stratigraphic and biologic significance. Eolol. Rev. 48: 221-224 [in Chinese, English abstr.].

KE Y.L. 2006: A study of Revision and Phylogeny of Genera in Anthocoridae (s. str.) of the World (Hemiptera: Heteroptera: Anthoridae). $\mathrm{PhD}$ thesis, Nankai University, $223 \mathrm{pp}$.

KerzhNer I.M. 1981: Heteroptera of the Family Nabidae. Fauna of the USSR. Insecta Rhynchota. Vol. 13. Pt 2. (N.S. No. 124). Nauka, Leningrad, $326 \mathrm{pp}$.

Latreille P.A. 1810: Considérations Générales sur l'Ordre Naturel des Animaux. F. Schoell, Paris, 460 pp.

Leston D., Pendergrast J.G. \& Southwood T.R.E. 1954: Classification of the terrestrial Heteroptera (Geocorisae). Nature 174: 91-92.

Li Y.L., Ren D. \& ShiH C.K. 2008: Two Middle Jurassic hanging-flies (Insecta: Mecoptera: Bittacidae) from Northeast China. Zootaxa 1929: 38-46.

Liu P.J., Huang J.D. \& Ren D. 2010: Palaeocology and structure of Yanliao entomofauna in the Middle Jurassic. Acta Zool. Sin. 35: 568-584 [in Chinese, English abstr.].

Liu Y.Q., Liu Y.X., Li P.X., Zhang H., Zhang L.J., Li Y. \& Xia H.D. 2004: Daohugou biota-bearing lithostratigraphic succession on the southeastern margin of the Ningcheng basin, Inner Mongolia, and its geochronology. Geol. Bull. China 23: 1180-1185.

Liu Y.S., Sinitshenkova N.D. \& Ren D. 2007: The oldest known record of Taeniopterygidae in the Middle Jurassic of Daohugou, Inner Mongolia, China (Insecta: Plecoptera). Zootaxa 1521: 1-8.

MCAlpine J.F. \& Martin J.E.H. 1969: Canadian amber - a palaeontological treasure chest. Can. Entomol. 101: 819-838. 
Popov Yu.A. 1990: Description of fossil insects. True bugs. Cimicina. In: Late Mesozoic Insects of Eastern Transbaikalia Tr. Paleont. Inst. Acad. Sci. USSR 239: 20-39 [in Russian].

Popov Yu.A. \& Herczek A. 2001: A new flower bug (Hemiptera: Heteroptera, Anthocoridae) from the Baltic amber. Prace Muzeum Ziemi 46: 55-58.

Popov Yu.A. \& Wootton R.J. 1977: The Upper Liassic Heteroptera of Mecklenburg and Saxony. Syst. Entomol. 2: 333-351.

Ren D., GaO K.Q. \& Guo Z.G. 2002: Stratigraphic dubusion of the jurassic in the daohugou area, Ningcheng, Inner Mongolia. Geol. Bull. China 21: 584-591 [in Chinese].

Ren D., Shin C.K., Gao T.P., Yao Y.Z. \& Zhao Y.Y. 2010: Silent Stories-Insect Fossil Treasures from Dinosaur Era of the Northeastern China. Science Press, Beijing, 322 pp.

Schun R.T. \& Slater J.A. 1995: True Bugs of the World (Hemiptera: Heteroptera). Classification and Natural History. Cornell University Press, Ithaca, New York, 336 pp.

Schun R.T \& ŚTYs P. 1991: Phylogenetic analysis of cimicomorphan family relationships (Heteroptera). J. N. Y. Entomol. Soc. 99: 298-350.

Schun R.T., Weirauch C. \& Wheeler W.C. 2009: Phylogenetic relationships within the Cimicomorpha (Hemiptera: Heteroptera): a total-evidence analysis. Syst. Entomol. 34: 15-48.

ShCherbakov D.E. 2007: Mesozoic Velocipedinae (Nabidae s.l.) and Ceresopseidae (Reduvioidea), with notes on the phylogeny of Cimicomorpha (Heteroptera). Russ. Entomol. J. 16: 401-414.

Shcherbakov D.E. \& Popov Y.A. 2002: 2.2.1.2.5. Superorder Cimicidea Laicharting, 1781. Order Hemiptera Linné, 1758. The bugs, cicads, scale insects, etc. In Rasnitsyn A.P. \& Quicke D.L.J. (eds): History of Insects. Kluwer Academic Publishers, Dordrecht, pp. 143-157.

Shen Y.B., Chen P.J. \& Huang D.Y. 2003: Age of the fossil conchostracans from Daohugou of Ningcheng, Inner Mongolia. J. Stratigraphy 27: 311-313.
Statz G. \& Wagner E. 1950: Geocorisae (Landwanzen) aus den Oberoligocner Ablagerungen von Rott. Palaeontographica (A) 98: 97-136.

Sun G., Zheng S.L., Dilcher D.L., Wang Y.D. \& Mei S.W. 2001: Early Angiosperms and their Associated Plants from Western Liaoning, China. Shanghai Scientific and Technological Education Publishing House, Shanghai, 227 pp. [in Chinese and English].

TAN J.J. \& Ren D. 2002: Palaeoecology of insect community from Middle Jurassic Jiulongshang formation in Ningcheng County, Inner Mongolia, China. Acta Zool. Sin. 27: 428-434 [in Chinese, English abstr.].

YAO Y.Z., CAI W.Z. \& ReN D. 2006a: Fossil flower bugs (Heteroptera: Cimicomorpha: Cimicoidea) from the Late Jurassic of Northeast China, including a new family, Vetanthocoridae. Zootaxa 1360: 1-40.

YAO Y.Z., CAI W.Z. \& REN D. 2006b: New fossil rhopalids (Heteroptera: Coreoidea) from the Middle Jurassic of Inner Mongolia, China. Zootaxa 1384: 41-58.

YAO Y.Z., CAI W.Z. \& REN D. 2008: New Jurassic fossil true bugs of the Pachymeridiidae (Hemiptera: Pentatomomorpha) from Northeast China. Acta Geol. Sin. 82: 35-47.

Zhang W. \& SHEN Y.B. 1987: Discovery of Jurassic conchostracans with well-preserved soft parts and notes on its biological significance. Acta Palaeontol. Sin. 26: 127-145 [in Chinese, English abstr.].

ZheNG L.Y. 1999: Class Insecta: Order Hemiptera: Suborder Heteroptera (= Order Hemiptera s. str.). In Zheng L.Y. \& Gui H. (eds): Insect Classification. Naniing Normal University Press, Nanjing, pp. 442-520 [in Chinese].

Zhou Z.Y., Zheng S.L. \& Zhang L.J. 2007: Morphology and age of Yimaia (Ginkgoales) from Daohugou Village, Ningcheng, Inner Mongolia, China. Cretac. Res. 13: 207-262.

Received August 12, 2011; revised and accepted November 1, 2011 